\title{
Effectiveness of Recovered Magnesium Phosphates as Fertilizers in Neutral and Slightly Alkaline Soils
}

\author{
Michael S. Massey, Jessica G. Davis,* James A. Ippolito, and Ronald E. Sheffield
}

\begin{abstract}
Magnesium phosphates such as struvite $\left(\mathrm{MgNH}_{4} \mathrm{PO}_{4} \cdot 6 \mathrm{H}_{2} \mathrm{O}\right)$ can be recovered from municipal, industrial, and agricultural wastewaters. However, limited information is available on the beneficial reuse of these recovered products; research has focused on low $\mathrm{pH}$ soils. This study determined whether recovered struvite and dittmarite $\left(\mathrm{MgNH}_{4} \mathrm{PO}_{4} \cdot \mathrm{H}_{2} \mathrm{O}\right)$ were effective $\mathrm{P}$ fertilizers in neutral to slightly alkaline soils. In addition to commercially available triple superphosphate (TSP) and certified organic rock phosphate (RP), recovered struvite, dittmarite, and a heterogeneous recovered phosphate were evaluated in a laboratory dissolution study and as fertilizers for spring wheat (Triticum aestivum L.) in a greenhouse study. Struvite and dittmarite were much more soluble than RP, but less soluble than TSP. Laboratory dissolution kinetics were fast, with most materials nearing equilibrium within 7 to $14 \mathrm{~d}$. At a soil $\mathrm{pH}$ of 6.5 , both dittmarite and struvite increased the average plant $\mathrm{P}$ concentration over the control. Struvite and dittmarite performance was similar to TSP. There were no significant differences in plant dry matter (DM) production or total $\mathrm{P}$ uptake at $\mathrm{pH}$ 6.5. In the limed soil ( $\mathrm{pH}$ 7.6), many treatments had plant $\mathrm{P}$ concentrations significantly lower than the control, but most fertilizers increased DM production over the control; all fertilizers generally performed similarly to one another. These findings support previous work showing recovered $\mathrm{Mg}$ phosphates to be effective in acidic soils, and provide evidence that they are also effective in slightly alkaline soils. Recovered $\mathrm{Mg}$ phosphates could become a useful alternative for $\mathrm{P}$ fertilization in arid and semiarid environments.
\end{abstract}

$\mathrm{E}$ NRICHMENT OF SURFACE WATERS with P from municipal wastewater treatment discharge or agricultural runoff is an important water quality concern that can lead to eutrophication (Carpenter et al., 1998). The recovery of P by crystallization from municipal and agricultural wastewater has the potential to reduce eutrophication while creating relatively pure, useful byproducts. While it is unclear exactly how long existing RP reserves will last, $\mathrm{P}$ is a limited resource and its reuse is necessary for the long-term sustainability of agricultural and industrial production (Driver et al., 1999). Recovery efforts have focused on wastewater treatment plants (WWTPs), where spontaneous struvite precipitation can be destructive to facility operations (de-Bashan and Bashan, 2004). There exist several full-scale, working examples of WWTPs using crystallization processes for P removal. Depending on the process, the product recovered is either Ca phosphate (apatite) or Mg phosphate (struvite, dittmarite, or newberyite) (Driver et al., 1999; de-Bashan and Bashan, 2004). At least one plant sells recovered struvite

M.S. Massey, Dep. of Environmental Earth System Sci., Stanford Univ., Stanford, CA 94305; J.G. Davis, Inst. for Livestock and the Environment, Colorado State Univ., Fort Collins, CO 80523-1170; J.A. Ippolito, USDA-ARS NWISRL, 3793 North 3600 East, Kimberly, ID, 83341; R.E. Sheffield, Dep. of Biological and Agricultural Engineering, Louisiana State Univ. AgCenter, Baton Rouge, LA 70803-4505. Received 2 May 2008. ${ }^{*}$ Corresponding Author (Jessica.Davis@colostate.edu).

Published in Agron. J. 101:323-329 (2009).

doi:10.2134/agronj2008.0144

Copyright $\odot 2009$ by the American Society of Agronomy, 677 South Segoe Road, Madison, WI 53711. All rights reserved. No part of this periodical may be reproduced or transmitted in any form or by any means, electronic or mechanical, including photocopying, recording, or any information storage and retrieval system, without permission in writing from the publisher.
$\left(\mathrm{MgNH}_{4} \mathrm{PO}_{4} \cdot 6 \mathrm{H}_{2} \mathrm{O}\right)$ as a slow-release component of a commercial fertilizer mix (Ueno and Fujii, 2001).

Recently, on-site P removal from agricultural wastewater has become a focal point of research. Greaves et al. (1999) noted that $\mathrm{P}$ is typically more concentrated in manures than in sewage, making manure an ideal target for P recovery. The authors also noted that while land application is the preferable method of manure P reuse, application of manure to meet crop $\mathrm{N}$ needs can result in the overapplication of $\mathrm{P}$. Phosphorus recovery through crystallization could be used to correct this imbalance, and could also reduce a farm's land base requirement. Ideally, a crystalline product for agricultural reuse would have a high P concentration and could be easily dried, handled, marketed, and transported at a fraction of the cost of manure or compost.

A number of wastewater P removal technologies exist, such as that outlined by Bowers and Westerman (2005a, 2005b), which utilizes a cone-shaped fluidized bed crystallizer. However, very few studies have evaluated the use of the recovered products. Many recovery processes focus on $\mathrm{Mg}$ phosphates such as struvite, but few applications for recovered struvite have been tested. The chemical composition of struvite makes it impractical for use as a raw material in the modern P industry (Driver et al., 1999; Schipper et al., 2001). Bridger et al. (1962) noted the effectiveness of struvite and dittmarite as fertilizer for turf, on ornamentals and flowers, in forests and orchards, and even on field crops. More recently, Johnston and Richards (2003) compared a variety of recovered phosphate fertilizers in a greenhouse setting, and found recovered struvite to be an effective fertilizer for ryegrass on soils with $\mathrm{pH} 6.6$ and 7.1. Recovered struvite from a Hong Kong landfill leachate was

Abbreviations: DM, dry matter; RP, rock phosphate; TSP, triple superphosphate; WWTP, wastewater treatment plant. 
found to be as effective as commercial fertilizer for vegetables grown on a nutrient-poor soil with pH 6.2 ( $\mathrm{Li}$ and Zhao, 2003). Goto (1998) found recovered struvite granules to be an effective fertilizer for winter greens in a soil with $\mathrm{pH} 5.8$ that had been amended with lime to an unspecified $\mathrm{pH}$ level. Bauer et al. (2007) examined the usefulness of recovered Ca phosphates in a greenhouse setting, on soil with a $\mathrm{pH}$ of 4.9, amended with lime to $\mathrm{pH}$ 6.5. The amorphous Ca phosphates were fairly soluble, with a large amount of plant-available $\mathrm{P}$, and were nearly as effective as TSP.

Rothbaum and Rohde (1976) suggested that struvite dissolution might be increased by an aerobic microbiological mineralization mechanism, though this finding has not subsequently been investigated. Mackay and Syers (1986) found that high Ca concentration in the soil solution inhibited the dissolution of Ca phosphate rock. Increased P availability through biotic or abiotic factors might make recovered $\mathrm{Mg}$ phosphate a useful alternative $P$ fertilizer that is not as inhibited by high Ca concentrations typically found in alkaline and calcareous soils.

Phosphorus fertilization in alkaline soils can be challenging. This is especially true for certified organic growers, who cannot use conventionally manufactured fertilizers such as TSP. With the exception of manure and compost, other certified organic $P$ fertilizers such as RP and bone meal are not effective in calcareous soils (Chien and Menon, 1995; Elliott et al., 2007) Bolland et al. (1986) even found RP to be ineffective at mildly acidic $(\mathrm{pH} \sim 6)$ soil $\mathrm{pH}$. Phosphorus recovery and reuse from livestock waste could help alleviate P loading in areas with large numbers of livestock while providing producers with a valuable resource and potential source of additional revenue. The use of recovered $\mathrm{Mg}$ phosphates could improve the sustainability of livestock operations, and conventional and organic crop production in semiarid to arid areas containing alkaline and calcareous soils.

Documented studies could not be identified which specifically addressed the effectiveness of recovered $\mathrm{Mg}$ phosphates in alkaline or calcareous soils, even though Lindsay (1979) noted that $\mathrm{Mg}$ phosphates such as struvite might be more useful than Ca phosphates as fertilizers in such conditions. In this study, laboratory and greenhouse trials were conducted to determine the effectiveness of dittmarite $\left(\mathrm{MgNH}_{4} \mathrm{PO}_{4} \cdot \mathrm{H}_{2} \mathrm{O}\right)$, struvite, and a heterogeneous recovered phosphate material under neutral and slightly alkaline soil conditions.

\begin{tabular}{|c|c|c|c|c|}
\hline Fertilizert & $\mathrm{P}_{2} \mathrm{O}_{5}$ & Mg & $\mathrm{Ca}$ & $\mathrm{K}_{2} \mathrm{O}$ \\
\hline & & $\overline{4021}$ & & \\
\hline Struvite & $28.2(0.4)$ & $4.2(0.3)$ & $17.9(0.9)$ & $0.3(0.0)$ \\
\hline Dittmarite & $45.4(0.3)$ & $12.2(0.6)$ & $0.30(0.02)$ & $<0.1(0.0)$ \\
\hline Colorado product & I6.2(0.6) & $0.4 \mathrm{I}(0.0 \mathrm{I})$ & I8.3 (I.0) & $0.5(0.1)$ \\
\hline TSP† & $48.1(0.3)$ & $0.6 \mathrm{I}(0.03)$ & I3.7 (0.7) & $0.2(0.0)$ \\
\hline RPt & $21.7(0.1)$ & $0.10(0.01)$ & $25.4(0.6)$ & $0.2(0.0)$ \\
\hline
\end{tabular}

$\dagger \mathrm{RP}$, rock phosphate; TSP, triple superphosphate.

\section{MATERIALS AND METHODS}

\section{Laboratory Dissolution Study}

To assess the dissolution kinetics and equilibrium characteristics of different fertilizers and recovered phosphates at environmentally relevant $\mathrm{pH}$ levels, a laboratory-scale dissolution study was conducted. Three $\mathrm{pH}$ levels, 5.9, 7.0, and 8.0, were selected as most relevant to the soil environment. The $\mathrm{pH}$ 5.9 buffer consisted of $0.05 M$ potassium hydrogen phthalate adjusted to the target $\mathrm{pH}$ with sodium hydroxide. The $\mathrm{pH} 7.0$ and 8.0 buffers consisted of $0.05 M$ tris(hydroxymethyl)aminomethane adjusted to the target $\mathrm{pH}$ with hydrochloric acid. All chemicals were obtained from Thermo Fisher Scientific, Inc. (Pittsburgh, PA).

In addition to commercially available TSP and certified organic RP fertilizers, three recovered phosphates were tested. These include crystalline dittmarite from an Idaho food processing plant pump, crystalline struvite manufactured at a dairy in northwestern Washington, and a mixed product from a phosphorus recovery process at a Colorado dairy, hereafter referred to as Colorado product. The Colorado product consisted mainly of ground carbonate fluorapatite seed crystals, minute quantities of recovered magnesium phosphate, and sand grains from the bottom of the dairy manure storage lagoon. Fertilizers, including TSP, were digested using nitric and perchloric acid (Johnson and Ulrich, 1959). They were then analyzed for total P, Mg, Ca, and $\mathrm{K}$ at Ward Laboratories, Inc. in Kearney, NE (Table 1). Phosphorus was determined using a metavanadate yellow colorimetric method, measured at $430 \mathrm{~nm}$ (Padmore, 1990). Metals were measured by atomic absorption spectrophotometry (Isaac, 1990).

For each fertilizer, the total $\mathrm{P}$ equivalent of approximately $0.10 \mathrm{~g}$ of TSP was placed into plastic $50-\mathrm{mL}$ centrifuge tubes. Total $\mathrm{P}$ equivalents were determined using the average measured $\mathrm{P}$ concentrations of each material (Table 1). Approximately the same amount of $\mathrm{P}(0.021 \mathrm{~g}$, as $\mathrm{P})$ was placed into each tube. Then, $40 \mathrm{~mL}$ of buffer solution was added, and each set of tubes was placed on a reciprocating shaker at $120 \mathrm{rpm}$ for time increments of $1,4,7,14,35,75$, and $105 \mathrm{~d}$. The total length of time approximated that of a growing season. The experiment was set up in a 5 by 3 factorial design ( 5 treatments, $3 \mathrm{pH}$ levels), with 3 replicates (blocks) for each time-step. Following shaking, solutions were filtered through a $0.45-\mathrm{mm}$ syringe filter (Millipore, Inc.) and analyzed for P colorimetrically using an optimized ascorbic acid method (Rodriguez et al., 1994), or, in some cases, via inductively coupled plasma atomic emission spectrometry (Thermo Jarrell Ash IRIS Advantage, high resolution, dual view). Dissolution results were compared with those found by entering solid mineral phases at a fixed $\mathrm{pH}$ in PHREEQC Interactive version 2.15.0 (USGS, 2008).

\section{Greenhouse Fertilizer Trial}

A neutral to slightly acidic soil ( $\mathrm{pH} 6.5,0-15 \mathrm{~cm}$ depth) with a moderate amount of available $\mathrm{P}\left(31 \mathrm{mg} \mathrm{kg}^{-1}\right.$ Mehlich-3 P) was collected from a rangeland in northern Colorado. The soil was classified as fine-loamy over sandy or sandy-skeletal, mixed, mesic Aridic Argiustoll, 0 to 3\% slopes. The Altvan series consists of deep, well-drained soils that formed in mixed alluvial 
deposits (NRCS, 1980). Half of this soil was limed from an original $\mathrm{pH}$ of 6.5 to $\mathrm{pH} 7.6$ using pure calcium carbonate $\left(\mathrm{CaCO}_{3}\right.$, Thermo Fisher Scientific, Inc.). Approximately 5 $\mathrm{g} \mathrm{kg}^{-1} \mathrm{CaCO}_{3}$ total was added incrementally, a total of two times, until the proper $\mathrm{pH}$ was reached. The limed soil was moistened and dried several times to ensure $\mathrm{CaCO}_{3}$ dissolution, appropriate $\mathrm{pH}$ range, and $\mathrm{pH}$ stability. Soils were sieved through a $12.5-\mathrm{mm}$ mesh frame before potting to remove pebbles. The untreated and limed soils were analyzed for $\mathrm{pH}$, $\mathrm{NO}_{3}-\mathrm{N}, \mathrm{P}, \mathrm{K}$, organic carbon, and soluble salts at Servi-Tech, Inc. in Dodge City, KS (Table 2).

The same fertilizers used in the laboratory dissolution study were used in the greenhouse study. In addition to a control group which received no fertilizer, fertilizers were applied at two rates, $0.05 \mathrm{~g}$ and $0.1 \mathrm{~g} \mathrm{P}_{2} \mathrm{O}_{5}$ pot $^{-1}$, equivalent to 45 and 90 $\mathrm{kg} \mathrm{P}_{2} \mathrm{O}_{5}$ ha $^{-1}$ (to a depth of $15 \mathrm{~cm}$ ). The same amount of total $\mathrm{P}\left(0.05 \mathrm{~g}\right.$ or $\left.0.1 \mathrm{~g} \mathrm{P}_{2} \mathrm{O}_{5}\right)$ was applied to each pot receiving a given rate, even though the $P$ availability varied among fertilizer sources. Fertilizer treatments were mixed thoroughly with $2.5 \mathrm{~kg}$ of soil, placed in 3.8-L pots, and then organized in the greenhouse as a randomized complete block design with four replicates.

Pots were watered from the bottom with tap water approximately every other day, depending on sunlight and greenhouse temperature, to maintain soil moisture near field capacity. Hard red spring wheat (Triticum aestivum L. 'Zeke') was planted at a rate of 15 seeds per pot, and after germination, plants were thinned to eight plants per pot. Aboveground plant samples were collected, at 30-d intervals, by cutting plants approximately $10 \mathrm{~cm}$ above the soil surface. Plants were allowed to regrow after cutting, and formed a second set of seed heads before the final sample. A quantity of $30 \mathrm{~mL}$ of dilute $\mathrm{N}$ solution $\left(0.027 \mathrm{MNH}_{4} \mathrm{NO}_{3}\right)$ was applied after the first cutting and approximately every $2 \mathrm{wk}$ thereafter to eliminate the possibility of $\mathrm{N}$ limitation on $\mathrm{P}$ uptake. No $\mathrm{N}$ was applied before the first cutting to avoid the possibility of burning the seedlings. For the second and third cuttings, reproductive and vegetative growth were harvested and weighed separately. All cuttings

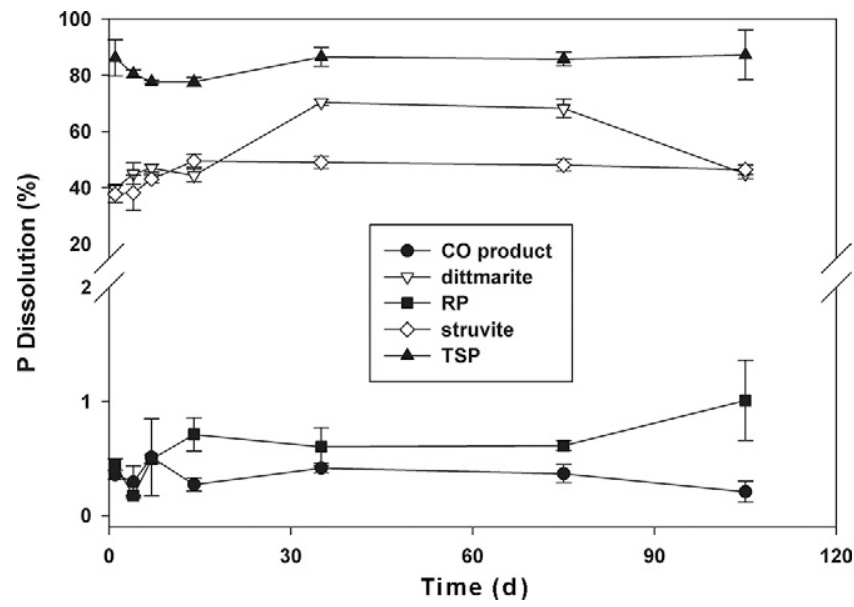

Fig. I. Mean values $(n=3)$ of the percentage $P$ dissolution for five fertilizer treatments at $\mathrm{pH}$ 5.9. Due to the great disparity between fertilizers with high and low dissolution, the percentage dissolution is presented on a split $y$ axis. Error bars represent one standard deviation. RP, rock phosphate; TSP, triple superphosphate.
Table 2. Average soil characteristics of the untreated and limed soils used in the greenhouse trials $(n=2)$. Soil pH and soluble salts were determined by measurement in a I: soil:water slurry, and organic carbon (OC) by a modified Walkley-Black (dichromate) method. Soil $\mathrm{NO}_{3}-\mathrm{N}$ was determined by $\mathrm{Cd}$ reduction, $\mathrm{P}$ was extracted by Mehlich-3, and $K$ was extracted with the ammonium acetate method. The increase in soil $\mathrm{NO}_{3}-\mathrm{N}$ may have been due to organic matter mineralization during liming.

\begin{tabular}{lcccccc}
\hline Soil & $\mathbf{p H}$ & $\mathbf{N O}_{3}-\mathbf{N}$ & $\mathbf{P}$ & $\mathbf{K}$ & $\mathbf{O C}$ & $\begin{array}{c}\text { Soluble } \\
\text { salts }\end{array}$ \\
\hline \multirow{3}{*}{ Unlimed } & 6.5 & 5 & 31 & 257 & $\mathrm{~g} \mathrm{~kg}^{-1}$ & $\mathrm{dS} \mathrm{m}^{-1}$ \\
Limed & 7.6 & 23 & 44 & 316 & 24 & 0.16 \\
\hline
\end{tabular}

were washed in deionized water, dried at $70^{\circ} \mathrm{C}$, ground, and sent to Ward Laboratories for total P analysis. Plant matter was digested using nitric and perchloric acid, and $\mathrm{P}$ was determined colorimetrically by the metavanadate yellow method (Johnson and Ulrich, 1959; Padmore, 1990).

Statistical analysis was performed using SAS version 9.1 (SAS Institute, Inc., Cary, NC, USA) PROC GLM. Block and treatment were modeled as fixed effects, with DM, P content, or $\mathrm{P}$ uptake as the response variable. Comparisons were made only between treatment means with the same soil $\mathrm{pH}$, due to large differences in variance between some high $\mathrm{pH}$ and low $\mathrm{pH}$ groups within the treatments. Multiple comparisons were made using Fisher's $F$-protected LSD at a significance level of $\alpha=0.10$.

\section{RESULTS AND DISCUSSION Laboratory Dissolution Study}

Dissolution kinetics were generally fast, with all treatments reaching approximate equilibrium within 7 to $14 \mathrm{~d}$ at all $\mathrm{pH}$ levels (Fig. 1-3). Two distinct groups of treatments were observed, those with high P availability (TSP, struvite, dittmarite) and those with low $\mathrm{P}$ availability (RP, Colorado product). As expected, commercial TSP was the most soluble ( 60-95\%), and solubility decreased with increasing $\mathrm{pH}$. Recovered struvite and dittmarite were essentially equivalent in

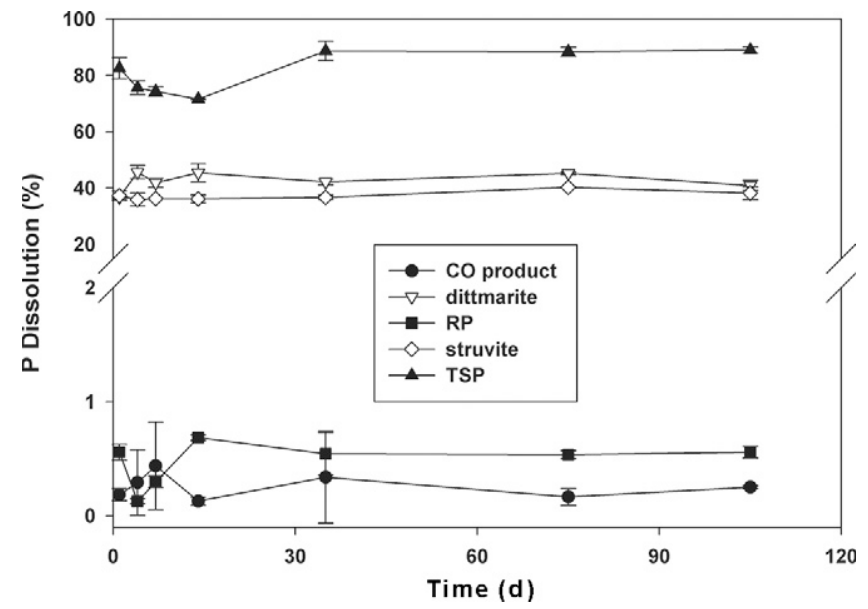

Fig. 2. Mean values $(n=3)$ of the percentage $P$ dissolution for five fertilizer treatments at $\mathrm{pH}$ 7.0. Due to the great disparity between fertilizers with high and low dissolution, the percent dissolution is presented on a split $y$ axis. Error bars represent one standard deviation. RP, rock phosphate; TSP, triple superphosphate. 


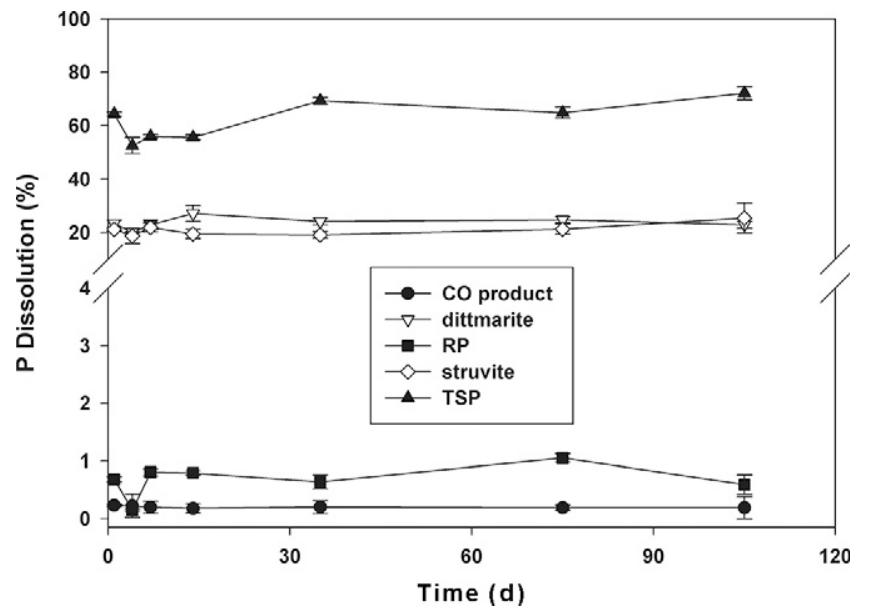

Fig. 3. Mean values $(n=3)$ of the percentage $P$ dissolution for five fertilizer treatments at $\mathrm{pH}$ 8.0. Due to the great disparity between fertilizers with high and low dissolution, the percent dissolution is presented on a split $y$ axis. Error bars represent one standard deviation. RP, rock phosphate; TSP, triple superphosphate.

terms of dissolution ( $15-40 \%)$, which was expected because in solution, dittmarite rehydrates to struvite before dissolution (Bridger et al., 1962; Bhuiyan et al., 2008). Struvite and dittmarite were less soluble than TSP, though more soluble than either RP or the Colorado product at all $\mathrm{pH}$ conditions. As with TSP, struvite and dittmarite solubility decreased with increasing $\mathrm{pH}$. The RP and Colorado product P solubility remained $<1 \%$ across the range of $\mathrm{pH}$ studied.

Across the $\mathrm{pH}$ range studied, the PHREEQC model predicted TSP to be most soluble, followed by struvite, and RP. Depending on $\mathrm{pH}$, the TSP $\mathrm{H}_{2} \mathrm{PO}_{4}$ or $\mathrm{HPO}_{4}$ equilibrium concentration was one to two and three to five orders of magnitude greater than struvite and RP, respectively. Dittmarite was not entered into the PHREEQC model because a solubility product could not be found. However, once introduced into solution, dittmarite is reported to rehydrate to struvite before dissolution (Bridger et al., 1962; Bhuiyan et al., 2008) and thus would follow struvite solubility closely. The Colorado product contained the mineral phase carbonate fluorapatite, a mixed $\mathrm{PO}_{4}-\mathrm{CO}_{3}$ member of the apatite group, and as such a solubility product could not be found and entered into PHREEQC. According to the FAO (2004), the solubility of carbonate fluorapatite with a maximum known amount of $\mathrm{CO}_{3}$ substitution is about 3\% P; this value decreases with decreasing $\mathrm{CO}_{3}$ substitution to a minimum of approximately $0.75 \% \mathrm{P}$. The solubility of igneous apatites (such as RP) are generally $\sim 0.43-0.86 \% \mathrm{P}$, similar to carbonate fluorapatite with minimal $\mathrm{CO}_{3}$ substitution (FAO, 2004).

Highly soluble P fertilizers can release P too quickly, while P fertilizers with low solubility release little P to the environment. In both cases, plant P deficiencies could easily occur later or throughout the growing season, respectively. Goto (1998) noted, however, that the moderate solubility of struvite makes it an attractive fertilizer in soils with high $\mathrm{P}$ fixation, such as soils rich in aluminum or $\mathrm{CaCO}_{3}$. In high P fixing soils, struvite's "slow release" characteristics might actually provide more $\mathrm{P}$ to plants over the course of the growing season than an immediately soluble P fertilizer such as TSP.

\section{Low pH Soil}

At low soil pH (6.5), there was no significant difference from the control in total DM production or in DM production at any single harvest, or in total $\mathrm{P}$ uptake over the course of the experiment (data not shown). Several of the fertilizer treatments, however, did result in increased $\mathrm{P}$ concentration in vegetative and seed material at low soil pH (Table 3 ). At certain cutting times, plants receiving dittmarite, Colorado product, TSP, and RP showed significant increases in $\mathrm{P}$ concentration as compared with the control. This was especially true at the higher P application rate. Overall, plants receiving struvite, dittmarite, and

Table 3. Average $\mathrm{P}$ concentrations for wheat grown on the low $\mathrm{pH}(6.5)$ soil. "Average" refers to the weighted average of plant and seed $P$ concentration, based on the relative amounts of oven-dried plant and seed material.

\begin{tabular}{|c|c|c|c|c|c|c|c|c|c|}
\hline Fertilizer treatment & $\begin{array}{c}P \text { rate as } \\
\mathbf{P}_{2} \mathrm{O}_{5}\end{array}$ & $\begin{array}{c}30 \text { d } \mathbf{P}, \\
\text { plant }\end{array}$ & $\begin{array}{c}60 \mathrm{~d} \mathbf{P}, \\
\text { plant }\end{array}$ & $\begin{array}{c}60 \mathrm{~d} \mathrm{P}, \\
\text { seed }\end{array}$ & $\begin{array}{c}60 \mathrm{~d} \mathbf{P}, \\
\text { average }\end{array}$ & $\begin{array}{c}90 \mathrm{~d} \mathbf{P}, \\
\text { plant }\end{array}$ & $\begin{array}{c}90 \mathrm{~d} \mathrm{P} \text {, } \\
\text { seed }\end{array}$ & $\begin{array}{c}90 \mathrm{~d} \mathrm{P}, \\
\text { average }\end{array}$ & $\begin{array}{c}\text { P overall } \\
\text { average }\end{array}$ \\
\hline & $\mathrm{kg} \mathrm{ha}^{-\mathrm{I}}$ & & & 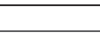 & $g$ & & & & \\
\hline \multirow[t]{2}{*}{ struvite } & 45 & 3.62 & 3.35 & 3.40 & 3.37 & 2.80 & 4.20 & 3.73 & 3.56 \\
\hline & 90 & 3.85 & $3.38 \dagger$ & 3.40 & 3.38 & $3.05 \dagger$ & 4.05 & 3.69 & $3.60 \dagger$ \\
\hline \multirow[t]{2}{*}{ dittmarite } & 45 & $3.98 \dagger$ & $3.60 \dagger$ & 3.50 & $3.57 \dagger$ & 2.78 & 4.22 & 3.70 & $3.71 \dagger$ \\
\hline & 90 & $4.03+$ & $3.75+$ & 3.72 & $3.73 \dagger$ & 2.38 & 4.12 & 3.50 & $3.68 t$ \\
\hline \multirow[t]{2}{*}{ Colorado product } & 45 & 3.80 & 2.95 & 3.28 & 3.07 & 2.65 & 4.00 & 3.57 & 3.41 \\
\hline & 90 & $3.90 \dagger$ & 3.10 & 3.68 & 3.39 & 2.32 & 3.78 & $3.20 \dagger$ & 3.47 \\
\hline \multirow[t]{2}{*}{$\mathrm{TSP} \ddagger$} & 45 & $3.92 \dagger$ & 3.22 & 3.38 & 3.28 & 2.98 & 4.00 & 3.63 & 3.54 \\
\hline & 90 & $4.12 \dagger$ & $3.52 \dagger$ & 3.42 & 3.49 & $3.15 t$ & 4.02 & 3.73 & $3.73 \dagger$ \\
\hline \multirow[t]{2}{*}{$\mathrm{RP} \ddagger$} & 45 & 3.75 & 3.02 & 3.28 & 3.12 & 2.90 & 3.92 & 3.58 & 3.42 \\
\hline & 90 & 3.50 & $3.40 \dagger$ & $4.10+$ & $3.52 \dagger$ & 2.38 & 3.88 & 3.34 & 3.32 \\
\hline control & 0 & 3.68 & 3.09 & 3.42 & 3.22 & 2.61 & 4.00 & 3.51 & 3.41 \\
\hline treatment effect $P$ value $\S$ & & 0.002 & 0.002 & 0.532 & 0.032 & 0.048 & 0.323 & 0.176 & 0.033 \\
\hline
\end{tabular}

$\dagger$ Indicates a $P$ concentration that is significantly different from the control $(P<0.10)$.

$\ddagger R P$, rock phosphate; TSP, triple superphosphate.

$\S$ The last row shows overall $P$ values of each comparison for the treatment effect from the Type III ANOVA table. 
Table 4. Average dry matter (DM) production (in grams per pot, oven-dry weight) for wheat grown on the high pH (7.6) soil.

\begin{tabular}{|c|c|c|c|c|c|c|c|c|c|}
\hline Fertilizer treatment & Rate & $\begin{array}{c}30 \text { d DM, } \\
\text { plant }\end{array}$ & $\begin{array}{l}60 \mathrm{~d} D M, \\
\text { plant }\end{array}$ & $\begin{array}{l}60 \mathrm{~d} D M, \\
\text { seed }\end{array}$ & $\begin{array}{l}60 \mathrm{~d} D M, \\
\text { total }\end{array}$ & $\begin{array}{l}90 \text { d DM, } \\
\text { plant }\end{array}$ & $\begin{array}{c}90 \mathrm{~d} \text { d } \mathrm{DM}, \\
\text { seed }\end{array}$ & $\begin{array}{c}90 \mathrm{~d}, \mathrm{DM} \\
\text { total }\end{array}$ & $\begin{array}{l}\text { DM overall } \\
\text { total }\end{array}$ \\
\hline \multirow{3}{*}{ Struvite } & $\mathrm{kg} \mathrm{ha}^{-1}$ & & & & $g \mathrm{p}$ & & & & \\
\hline & 45 & 1.99 & 2.18 & $1.48 \dagger$ & $3.66 \dagger$ & 1.12 & 1.96 & 3.08 & 8.73 \\
\hline & 90 & 1.98 & 2.18 & $1.52 \dagger$ & $3.70 \dagger$ & $1.49 \dagger$ & $2.52 \dagger$ & $4.01 t$ & $9.69 \dagger$ \\
\hline \multirow[t]{2}{*}{ Dittmarite } & 45 & 2.10 & 2.05 & $1.43 \dagger$ & 3.54 & $1.30 \dagger$ & $2.66 t$ & $3.96 \dagger$ & $9.59 \dagger$ \\
\hline & 90 & 2.05 & 2.16 & 1.48 & 3.43 & $1.42 \dagger$ & $2.62 \dagger$ & $4.04 \dagger$ & $9.52 \dagger$ \\
\hline \multirow[t]{2}{*}{ Colorado product } & 45 & 2.00 & $2.41 \dagger$ & 1.40 & $3.81 \dagger$ & $1.49 \dagger$ & $2.60 t$ & $4.09+$ & $9.90 \dagger$ \\
\hline & 90 & 1.99 & $2.42 \dagger$ & 1.32 & $3.74 \dagger$ & $1.72 \dagger$ & $2.99+$ & $4.71 t$ & $10.44 \dagger$ \\
\hline \multirow[t]{2}{*}{ TSP $\ddagger$} & 45 & $2.28 \dagger$ & 2.03 & 1.24 & 3.27 & $1.34 \dagger$ & $2.52 \dagger$ & $3.85 \dagger$ & $9.40 \dagger$ \\
\hline & 90 & 1.90 & $2.51 \dagger$ & $1.43 \dagger$ & $3.94 \dagger$ & $1.52 \dagger$ & $2.86 \dagger$ & $4.38 \dagger$ & $10.23 t$ \\
\hline \multirow[t]{2}{*}{$\mathrm{RP} \ddagger$} & 45 & 1.82 & $2.33 \dagger$ & 1.20 & 3.53 & 1.08 & 2.05 & 3.13 & 8.48 \\
\hline & 90 & 2.03 & $2.21^{\prime}$ & 1.32 & 3.53 & 1.23 & 2.22 & 3.45 & $9.02 \dagger$ \\
\hline Control & 0 & 1.85 & 1.83 & 1.14 & 2.97 & 0.94 & 1.63 & 2.57 & 7.39 \\
\hline Treatment effect $\mathrm{P}$ value & & 0.700 & 0.271 & 0.036 & 0.303 & 0.011 & 0.048 & 0.024 & 0.063 \\
\hline
\end{tabular}

$\dagger$ Indicates a $P$ concentration that is significantly different from the control $(P<0.10)$.

$\ddagger$ RP, rock phosphate; TSP, triple superphosphate.

$\S$ The last row shows overall $P$ values of each comparison for the treatment effect from the Type III ANOVA table.

TSP showed increases in P concentration as compared with the control (Table 3). In addition to outperforming the control in $\mathrm{P}$ concentration, dittmarite increased plant $\mathrm{P}$ concentration over that of the RP and the Colorado product treatments $(P<0.05)$. At the high application rate, TSP also significantly increased $P$ concentration over the high and low RP treatments $(P<0.01)$ and the high and low Colorado product treatments $(P<0.05)$.

Three factors potentially influencing the observations in the low $\mathrm{pH}$ soil were the soil $\mathrm{P}$ content, soil $\mathrm{P}$ availability, and soil organic matter content. At a soil $\mathrm{pH}$ of 6.5, P availability is typically optimal for many plants. The optimal $\mathrm{pH}$, coupled with this soil's moderate level of available P (Table 2), may have led to conditions sufficient for substantial DM production in the unfertilized pots. Another possibility is that of $\mathrm{P}$ release to plants through the mineralization of organic matter over the course of the experiment. The greenhouse in which the experiment was conducted was considered to be abnormally warm, so the temperature coupled with the irrigation of the pots could have created ideal conditions for microbiological mineralization of organic matter. Lack of significant differences in average plant $\mathrm{P}$ content in the last cutting suggests increased $\mathrm{P}$ availability, supporting this conclusion.

Although the addition of fertilizer did not increase DM production at low $\mathrm{pH}$ in this experiment, some of the fertilizers did increase plant $\mathrm{P}$ concentration both early in the experiment and overall. While RP and the Colorado product had an early effect, the overall average was not significantly different from the control mean P concentration of $3.4 \mathrm{~g} \mathrm{~kg}^{-1}$. Struvite and TSP significantly increased plant $P$ concentration at the high application rate, to $3.6 \mathrm{~g} \mathrm{~kg}^{-1}(P=0.047)$ and $3.7 \mathrm{~g} \mathrm{~kg}^{-1}$ $(P<0.01)$, respectively. Dittmarite increased overall average plant $P$ concentration at both the high and low rates of application to $3.7 \mathrm{~g} \mathrm{~kg}^{-1}(P<0.01)$. These findings support previous work (Goto, 1998; Johnston and Richards, 2003; Li and Zhao, 2003) that found recovered $\mathrm{Mg}$ phosphates to be effective fertilizers in slightly acidic soils.

\section{High pH Soil}

All fertilizers except RP and struvite at the low rate increased overall DM production over the control at high soil
$\mathrm{pH}$ (Table 4). The RP increased DM production at the high application rate $(P=0.08)$. That $\mathrm{RP}$ was less effective than other fertilizers at high soil $\mathrm{pH}$ was not a new finding. Mackay and Syers (1986) found that high Ca concentrations inhibit RP dissolution. Chien and Menon (1995) noted that high $\mathrm{pH}$ and high Ca concentration, in addition to other factors, limited the effectiveness of RP in soil. The Mg phosphate fertilizer treatments all showed increased DM production, supporting the contention that recovered $\mathrm{Mg}$ phosphates can indeed be used as fertilizers on alkaline soils. Field trials and further tests across a wide range of alkaline soil $\mathrm{pH}$ and $\mathrm{CaCO}_{3}$ content will help to determine the agronomic effectiveness of these fertilizers under alkaline soil conditions.

One matter of concern regarding the interpretation of plant $\mathrm{P}$ concentrations for the limed soil is the high average $\mathrm{P}$ concentration for the control, and relatively lower P concentrations in the fertilized plants (Table 5). This could be attributed to a dilution effect from increased DM production. Also perplexing is the increased soil test $\mathrm{P}$ in the limed soil (Table 1). These results seem counterintuitive, given the common perception that high $\mathrm{pH}$ and the presence of $\mathrm{CaCO}_{3}$ will inhibit $\mathrm{P}$ availability to plants, and the application of fertilizer to increase yields and plant $\mathrm{P}$ content. Indeed, liming of the soil was selected as a method of raising $\mathrm{pH}$ in this experiment, since the total $\mathrm{P}$ content of the soil does not change with the addition of $\mathrm{CaCO}_{3}$. The addition of large amounts of free $\mathrm{Ca}$ may unexpectedly have had the opposite effect on $\mathrm{P}$ availability, possibly by rendering $\mathrm{P}$ bound as $\mathrm{Fe}$ or $\mathrm{Al}$ phosphates more soluble. Alternately, wetting of the soil during liming may have increased available $P$ through organic matter mineralization. As a result of the increased available $P$ in the limed soil as compared with the unlimed soil, comparisons of $\mathrm{P}$ fertilizer performance in the low $\mathrm{pH}$ versus high $\mathrm{pH}$ soils were not possible. Liming may be an unsuitable choice to manipulate soil $\mathrm{pH}$ for similar P fertilizer experiments in the future. However, liming of soil for greenhouse studies is common practice, as seen in the studies by Goto (1998) and Bauer et al. (2007), so caution is warranted.

Many of the fertilized pots had lower plant $\mathrm{P}$ concentration than the control at high $\mathrm{pH}$ (Table 5). The decreased plant 
Table 5. Average P concentrations for wheat grown on the high pH (7.6) soil. "Average" refers to the weighted average of plant and seed $P$ concentration, based on the relative amounts of oven-dried plant and seed material.

\begin{tabular}{|c|c|c|c|c|c|c|c|c|c|}
\hline $\begin{array}{l}\text { Fertilizer } \\
\text { treatment }\end{array}$ & rate & $\begin{array}{l}30 \mathrm{~d} P, \\
\text { plant }\end{array}$ & $\begin{array}{l}60 \mathrm{~d} P, \\
\text { plant }\end{array}$ & $\begin{array}{l}60 \mathrm{~d} P \text {, } \\
\text { seed }\end{array}$ & $\begin{array}{c}60 \mathrm{~d} P, \\
\text { average }\end{array}$ & $\begin{array}{l}90 \mathrm{~d} P, \\
\text { plant }\end{array}$ & $\begin{array}{c}90 \mathrm{~d} P, \\
\text { seed }\end{array}$ & $\begin{array}{c}90 \mathrm{~d} \mathbf{P}, \\
\text { average }\end{array}$ & $\begin{array}{l}\mathbf{P} \text { overall } \\
\text { average }\end{array}$ \\
\hline Struvite & $\begin{array}{c}\mathrm{kg} \mathrm{ha}^{-1} \\
45 \\
90\end{array}$ & $\begin{array}{l}4.10 \\
4.18 \dagger\end{array}$ & $\begin{array}{l}3.45 \dagger \\
3.20 \dagger\end{array}$ & $\begin{array}{l}3.65 \\
3.58 \dagger\end{array}$ & $\begin{array}{l}3.53 \dagger \\
3.36 \dagger\end{array}$ & $\begin{array}{l}3.70 \\
3.62\end{array}$ & $\begin{array}{l}4.15 \\
3.95\end{array}$ & $\begin{array}{l}3.98 \\
3.82 \dagger\end{array}$ & $\begin{array}{l}3.84 \dagger \\
3.69 \dagger\end{array}$ \\
\hline Dittmarite & $\begin{array}{l}45 \\
90\end{array}$ & $\begin{array}{l}4.10 \\
4.15\end{array}$ & $\begin{array}{l}3.53 \dagger \\
3.60\end{array}$ & $\begin{array}{l}3.55 \dagger \\
3.72\end{array}$ & $\begin{array}{l}3.54 \dagger \\
3.65\end{array}$ & $\begin{array}{l}4.05 \\
3.68\end{array}$ & $\begin{array}{l}4.12 \\
4.32\end{array}$ & $\begin{array}{l}4.10 \\
4.09\end{array}$ & $\begin{array}{l}3.89 \\
3.93\end{array}$ \\
\hline Colorado product & $\begin{array}{l}45 \\
90\end{array}$ & $\begin{array}{l}3.90 \\
3.98\end{array}$ & $\begin{array}{l}3.43 \dagger \\
3.28 \dagger\end{array}$ & $\begin{array}{l}3.62 \\
3.55 \dagger\end{array}$ & $\begin{array}{l}3.50 \dagger \\
3.37 \dagger\end{array}$ & $\begin{array}{l}3.05 \dagger \\
3.45\end{array}$ & $\begin{array}{l}4.02 \\
3.92 \dagger\end{array}$ & $\begin{array}{l}3.67 \dagger \\
3.75 \dagger\end{array}$ & $\begin{array}{l}3.65 \dagger \\
3.66 \dagger\end{array}$ \\
\hline $\mathrm{TSP} \ddagger$ & $\begin{array}{l}45 \\
90\end{array}$ & $\begin{array}{l}4.00 \\
3.98\end{array}$ & $\begin{array}{l}3.40 \dagger \\
3.38 \dagger\end{array}$ & $\begin{array}{l}3.50 \dagger \\
3.52 \dagger\end{array}$ & $\begin{array}{l}3.44 \dagger \\
3.43 \dagger\end{array}$ & $\begin{array}{l}3.65 \\
3.80\end{array}$ & $\begin{array}{l}4.08 \\
3.95 \dagger\end{array}$ & $\begin{array}{l}3.93 \\
3.89\end{array}$ & $\begin{array}{l}3.74 \dagger \\
3.72 \dagger\end{array}$ \\
\hline $\mathrm{RP} \ddagger$ & $\begin{array}{l}45 \\
90\end{array}$ & $\begin{array}{l}4.10 \\
3.90\end{array}$ & $\begin{array}{l}3.48 \dagger \\
3.40 \dagger\end{array}$ & $\begin{array}{l}3.58 \dagger \\
3.58 \dagger\end{array}$ & $\begin{array}{l}3.50 \dagger \\
3.46 \dagger\end{array}$ & $\begin{array}{l}4.25 \\
3.35 t\end{array}$ & $\begin{array}{l}4.22 \\
4.02\end{array}$ & $\begin{array}{l}3.76 \\
3.63 \dagger\end{array}$ & $\begin{array}{l}3.87 \\
3.69 \dagger\end{array}$ \\
\hline Control & 0 & 3.95 & 3.86 & 3.89 & 3.88 & 4.09 & 4.26 & 4.22 & 4.01 \\
\hline Treatment effect $P$ value & & 0.420 & 0.042 & 0.402 & 0.055 & 0.270 & 0.287 & 0.166 & 0.007 \\
\hline
\end{tabular}

$\dagger$ Indicates a $P$ concentration that is significantly different from the control $(P<0.10)$.

$\ddagger R P$, rock phosphate; TSP, triple superphosphate.

$\S$ The last row shows overall $P$ values of each comparison for the treatment effect from the Type III ANOVA table.

$\mathrm{P}$ concentrations were the result of a dilution effect resulting from greater DM production in the fertilized pots, so total $\mathrm{P}$ uptake provides a more complete picture of the effectiveness of the $\mathrm{P}$ fertilizers in this case. Although the treatment effect for total P uptake $(\mathrm{DM} \times \mathrm{P}$ concentration) was not statistically significant $(P=0.144)$, the high level of significance of certain individual pairwise comparisons is important to note (Table 6). These pairwise comparisons show a trend of increased total $P$ uptake for all of the treatments except RP and low rate struvite as compared with the control. There were no significant differences among the noncontrol treatments, demonstrating that struvite, dittmarite, and even the heterogeneous Colorado product performed similarly to commercial TSP in high $\mathrm{pH}$, high $\mathrm{Ca}$ soil conditions. Given the ineffective nature of RP in these particular environments, recovered $\mathrm{Mg}$ phosphates might

Table 6. Total $\mathrm{P}$ uptake for wheat grown on the high $\mathrm{pH}$ (7.6) soil. Total $\mathbf{P}$ uptake was determined using the total $D M$ production and the overall weighted average $P$ concentration. Standard deviations are listed in parentheses. $P$ values shown in the table are for a two-sided comparison with the control using SAS PROC GLM.

\begin{tabular}{lccc}
\hline $\begin{array}{c}\text { Fertilizer } \\
\text { treatment }\end{array}$ & Rate & Total P uptake & P value \\
\hline \multirow{2}{*}{ Struvite } & $\mathrm{kg} \mathrm{ha}^{-1}$ & $\mathrm{mg}$ & \\
& 45 & $33(4)$ & 0.210 \\
Dittmarite & 90 & $36(5) \dagger$ & 0.052 \\
& 45 & $37(4) \dagger$ & 0.017 \\
Colorado product & 90 & $37(5) \dagger$ & 0.016 \\
& 95 & $36(6) \dagger$ & 0.040 \\
TSP $\ddagger$ & 90 & $38(4) \dagger$ & 0.008 \\
& 45 & $35(6) \dagger$ & 0.065 \\
RP $\ddagger$ & 90 & $38(1) \dagger$ & 0.010 \\
& 45 & $32(10)$ & 0.035 \\
Control & 90 & $33(5)$ & 0.252 \\
\hline
\end{tabular}

† Indicates a $\mathrm{P}$ concentration that is significantly different from the control $(P<0.10)$. $\ddagger R P$, rock phosphate; TSP, triple superphosphate. $\S N / A$, not applicable. provide certified organic producers with a viable alternative for $\mathrm{P}$ fertilization on alkaline and calcareous soils.

\section{CONCLUSION}

The recovery and beneficial reuse of phosphate has the potential to help protect water quality, improve the efficient cycling of $\mathrm{P}$ (a limited resource), and provide sources of revenue and materials for producers and consumers of phosphate. Recovery technologies have focused on the crystallization of $\mathrm{Mg}$ phosphates such as struvite and dittmarite, which cannot be recycled as a raw material for the current phosphate industry but have potential as fertilizer. Several studies have documented the effectiveness of $\mathrm{Mg}$ phosphates in acidic soils, but no known body of work examining recovered Mg phosphate usefulness under alkaline soil conditions exists. This study found evidence that recovered $\mathrm{Mg}$ phosphates may be useful in neutral to slightly alkaline soil conditions. Recovered Mg phosphates increased wheat $P$ concentration in neutral soil conditions, and increased plant DM production in alkaline soil conditions. A trend showing that Mg phosphates and TSP increased total $\mathrm{P}$ uptake was also evident under alkaline conditions, though it was not statistically significant. No such trend in total P uptake was observed for the fertilizers under acidic soil conditions. These results indicate that recovery of $\mathrm{Mg}$ phosphates could be an effective source of $\mathrm{P}$ fertilizer in areas with both acidic and alkaline soils.

\section{ACKNOWLEDGMENTS}

The authors would like to thank the NRCS, Farm Pilot Project Coordination, Inc., and Applied Chemical Magnesias Corp. for financial support. Special thanks goes to John Stromberger at Colorado State University for providing seed and sharing his expertise and time. Thanks also to Dr. K. Bowers of Multiform Harvest, Inc., for providing recovered struvite crystals. Finally, we are grateful for the assistance of two anonymous reviewers, four dairy owners in Colorado, Dr. R. Ward, Jennifer Matsuura, Lucas Mouttet, Kathy Doesken, Adriane Elliott, Robert Young, and Michael Smith. 


\section{REFERENCES}

Bauer, P.J., A.A. Szogi, and M.B. Vanotti. 2007. Agronomic effectiveness of calcium phosphate recovered from liquid swine manure. Agron. J. 99:1352-1356.

Bhuiyan, M.I.H., D.S. Mavinic, and F.A. Koch. 2008. Thermal decomposition of struvite and its phase transition. Chemosphere 70:1347-1356.

Bolland, M.D.A., A.J. Weatherley, R.J. Gilkes, and J.W. Bowden. 1986. Granular reactive apatite rock phosphate is not an effective phosphorus fertilizer in the short term on lateritic soils in south-western Australia. Aust. J. Exp. Agric. 26:217-225.

Bowers, K.E., and P.W. Westerman. 2005a. Design of cone-shaped fluidized bed struvite crystallizers for phosphorus removal from wastewater. Trans. ASAE 48:1217-1226.

Bowers, K.E., and P.W. Westerman. 2005b. Performance of cone-shaped fluidized bed struvite crystallizers in removing phosphorus from wastewater. Trans. ASAE 48:1227-1234.

Bridger, G.L., M.L. Salutsky, and R.W. Starostka. 1962. Metal ammonium phosphates as fertilizers. Agric. Food Chem. 10:181-188.

Carpenter, S.R., N.F. Caraco, D.L. Correll, R.W. Howarth, A.N. Sharpley, and V.H. Smith. 1998. Nonpoint pollution of surface waters with phosphorus and nitrogen. Ecol. Appl. 8:559-568.

Chien, S.H., and R.G. Menon. 1995. Factors affecting the agronomic effectiveness of phosphate rock for direct application. Fert. Res. 41:227-234.

de-Bashan, L.E., and Y. Bashan. 2004. Recent advances in removing phosphorus from wastewater and its future use as fertilizer. Water Res. 38:4222-4246.

Driver, J., D. Lijmbach, and I. Steen. 1999. Why recover phosphorus for recycling, and how? Environ. Technol. 20:651-662.

Elliott, A.L., J.G. Davis, R.M. Waskom, J.R. Self, and D.K. Christensen. 2007. Phosphorus fertilizers for organic farming systems. Publ. No. 0.569. Colorado State Univ. Coop. Ext., Fort Collins, CO.

FAO. 2004. Characterization of phosphate rocks. p. 17-24. In F. Zapata and R.N. Roy (ed.) Use of phosphate rocks for sustainable agriculture. Fertilizer and plant nutrition Bull. 13. Available at ftp://ftp.fao.org/docrep/ fao/007/y5053e/y5053e00.pdf [accessed 13 Nov. 2008; verified 28 Jan. 2009]. FAO, Rome.

Goto, I. 1998. Application of phosphorus recovered from sewage treatment facilities. (In Japanese.) Kankyou Gijutsu 27:418-422.

Greaves, J., P. Hobbs, D. Chadwick, and P. Haygarth. 1999. Prospects for the recovery of phosphorus from animal manures: A review. Environ. Technol. 20:697-708.
Isaac, R.A. 1990. Metals in Plants-Atomic absorption spectrophotometric method. Method 975.03. In K. Helrich (ed.) Official methods of analysis of the Association of Official Analytical Chemists. 15th ed. AOAC, Arlington, VA.

Johnson, C.M., and A. Ulrich. 1959. Analytical methods for use in plant analysis. Bull. 766. California Agric. Exp. Stn., Berkeley.

Johnston, A.E., and I.R. Richards. 2003. Effectiveness of different precipitated phosphates as phosphorus sources for plants. Soil Use Manage. 19:45-49.

Li, X.Z., and Q.L. Zhao. 2003. Recovery of ammonium-nitrogen from landfill leachate as a multi-nutrient fertilizer. Ecol. Eng. 20:171-181.

Lindsay, W.L. 1979. Chemical equilibria in soils. John Wiley \& Sons, New York.

Mackay, A.D., and J.K. Syers. 1986. Effect of phosphate, calcium, and $\mathrm{pH}$ on the dissolution of a phosphate rock in soil. Fertil. Res. 10:175-184

NRCS. Soil Survey of Larimer County Area, Colorado. 1980. Available at http://soils.usda.gov/survey/online_surveys/colorado/larimer/TextPart\%201.pdf [accessed 13 Nov. 2008; verified 28 Jan. 2009]. USDA, Washington, DC.

Padmore, J.M. 1990. Phosphorus in animal feed-Photometric method. Method No 965.17. In K. Helrich (ed.) Official methods of analysis of the Association of Official Analytical Chemists. 15th ed. AOAC, Arlington, VA.

Rodriguez, J.B., J.R. Self, and P.N. Soltanpour. 1994. Optimal conditions for phosphorus analysis by the ascorbic acid-molybdenum blue method. Soil Sci. Soc. Am. J. 58:866-870.

Rothbaum, H.P., and A.G. Rohde. 1976. Long-term leaching of nutrients from magnesium ammonium phosphate at various temperatures. N.Z. J. Exp. Agric. 4:405-413.

Schipper, W.J., A. Klapwik, B. Potjer, W.H. Rulkens, B.G. Temmink, F.D.G. Kiestra, and A.C.M. Lijmbach. 2001. Phosphate recycling in the phosphorus industry. Environ. Technol. 22:1337-1345.

Ueno, Y., and M. Fujii. 2001. Three years experience of operating and selling recovered struvite from full-scale plant. Environ. Technol. 22:1373-1381.

USGS. 2008. PHREEQC Interactive. Version 2.15.0. Available at http:// wwwbrr.cr.usgs.gov/projects/GWC_coupled/phreeqci/ [modified 11 Feb. 2008; accessed 13 Nov. 2008; verified 28 Jan. 2009]. USGS, Reston, VA. 